\title{
Karakter Seleksi pada Generasi Awal untuk Adaptasi Padi terhadap Cekaman Suhu Tinggi
}

\author{
Selection characters in Early Generation for Adaptation of Rice to High Temperature Stress
}

\author{
Victor Manotar Pademan Manalu ${ }^{1}$, Desta Wirnas ${ }^{2 *}$, dan Sudarsono ${ }^{2}$ \\ 'Program Studi Pemuliaan dan Bioteknologi Tanaman, Sekolah Pascasarjana, Institut Pertanian Bogor \\ ${ }^{2}$ Departemen Agronomi dan Hortikultura, Fakultas Pertanian, Institut Pertanian Bogor \\ (Bogor Agricultural University), Jl. Meranti, Kampus IPB Darmaga, Bogor 16680, Indonesia
}

Diterima 4 Februari 2016/Disetujui 12 Agustus 2016

\begin{abstract}
Developing new rice varieties adaptive to heat stress is important to maintain high rice production in anticipating global warming effects. This research was aimed to find selection characters and to select the best segregant in early generation based on agronomic characters for adaptation of rice to heat stress. The experiment was carried out in September 2014 to Januari 2015. About 210 F2 segregants generated trough hybridization between IPB 4S (sensitive parent) and Situ Patenggang (tolerant parent), 20 individuals of IPB 4S, and 20 individuals of Situ Patenggang, were used as genetic control. All genetic materials were exposed to high temperature stress by growing in a green house of Bogor Agricultural University. The average temperature in the research period was $24^{\circ} \mathrm{C}$ and $42.09^{\circ} \mathrm{C}$, respectively for minimum and maximum temperature. The results showed that charachters of productive and total tiller number, total grain number, and seed weight had high heritability, high coeffiecient of genetics variability-with an additive gene action. That charachters could be proposed as selection criteria in early generation for rice breeding of adaptation to high temperature stress. The characters could be applied in either single trait or multiple traits selection. Based on multiple traits selection we found 50 the best F2 segregation.
\end{abstract}

Keywords: differential selection, early generation, heat tolerant, heritability, gene action, variability genetics coeffiecient

\section{ABSTRAK}

Pengembangan varietas padi yang toleran terhadap cekaman suhu tinggi diperlukan untuk keberlanjutan produksi padi dalam antisipasi pemanasan global di masa yang akan datang. Penelitian ini bertujuan untuk mencari kriteria karakter seleksi dan memilih segregan terbaik di generasi awal berdasarkan beberapa karakter agronomi untuk adaptasi padi terhadap cekaman suhu tinggi. Penelitian dilaksanakan dari bulan September 2014 sampai bulan Januari 2015. Materi genetik yang digunakan adalah 210 individu segregan F2 yang berasal dari persilangan IPB 4S dan Situ Patenggang, 20 individu tetua IPB 4S, 20 individu tetua Situ Patenggang. Semua materi genetik ditanam dalam kondisi tercekam suhu tinggi di rumah kaca Institut Pertanian Bogor. Rata-rata suhu minimum dan maksimum pada penelitian ini adalah $24{ }^{\circ} \mathrm{C}$ dan $42.09^{\circ} \mathrm{C}$. Hasil penelitian menunjukkan bahwa karakter: jumlah anakan produktif dan total, jumlah gabah bernas, dan bobot gabah bernas memiliki nilai heritabilitas yang tinggi, aksi gen aditif, dan koefisien keragaman genetik yang tinggi. Karakter-karakter tersebut dapat dijadikan kriteria seleksi pada generasi awal untuk adaptasi padi terhadap cekaman suhu tinggi. Karakter seleksi dapat dilakukan baik dengan satu karakter atau beberapa kriteria karakter. Berdasarkan seleksi multikarakter didapatkan 50 segregan F2 terbaik.

Kata kunci: aksi gen, generasi awal, heritabilitas, koefisien keragaman genetik, padi, toleran suhu tinggi

\section{PENDAHULUAN}

Padi (Oryza sativa L.) merupakan salah satu tanaman tanaman pangan yang di konsumsi oleh lebih dari setengah penduduk dunia dan kebutuhannya terus meningkat (Krishnalatha dan Sharma 2012). Salah satu tantangan dalam mempertahankan produksi pangan, khususnya beras adalah

*Penulis untuk korespondensi. e-mail: desta.wirnas@yahoo.com perubahan iklim global yang ditandai dengan peningkatan suhu muka bumi. IPCC (2007) melaporkan bahwa pada akhir abad ke-21 suhu permukaan bumi akan meningkat sebesar rata-rata $2-4{ }^{\circ} \mathrm{C}$.

Peningkatan suhu muka bumi diperkirakan akan menjadi salah satu cekaman abiotik, yaitu cekaman suhu tinggi. Cekaman suhu tinggi dapat menjadi salah satu faktor pembatas dalam upaya peningkatan produktivitas padi. Menurut Wahid et al. (2007) cekaman suhu tinggi didefinisikan sebagai kenaikan suhu yang melebihi 
kisaran optimum sehingga menyebabkan kerusakan yang tidak dapat balik (irreversible) pada pertumbuhan dan perkembangan tanaman. Suhu optimum untuk pertumbuhan dan perkembangan padi berkisar $27-32{ }^{\circ} \mathrm{C}$ (Yoshida, 1978). Wassmann et al. (2009) menyatakan bahwa suhu optimum padi berada pada suhu sekitar $33^{\circ} \mathrm{C}$.

Penelitian menunjukkan bahwa peningkatan suhu secara langsung akan mempengaruhi pertumbuhan dan perkembangan tanaman padi (Yoshida, 1978; Wassmann et al., 2009), mulai dari perkecambahan, pertumbuhan vegatatif sampai dengan pertumbuhan generatif(Jagadish et al., 2008). Cekaman suhu tinggi selama fase berbunga padi menyebabkan penurunan vigor serbuk sari, dan fertilitas spikelet (Prasad et al., 2006; Jagadish et al., 2011; Poli et al., 2013). Penurunan vigor serbuk sari dapat dianggap sebagai faktor fisiologi yang bertanggung jawab terhadap penurunan produksi gabah pada kondisi suhu tinggi (Tang et al., 2008; Zhang et al., 2008; Xiao et al., 2011).

Sifat toleransi padi terhadap cekaman suhu tinggi dapat diperbaiki melalui pemuliaan tanaman dengan cara seleksi. Menurut Roy (2000), keberhasilan seleksi atau efisiensi seleksi ditunjukkan oleh perolehan kemajuan genetik dari genotipe terpilih. Kemajuan genetik yang diperoleh sangat tergantung kepada variabilitas genetik dan heritabilitas karakter seleksi. Perolehan kemajuan genetik dapat dimaksimalkan dengan memilih karakter seleksi yang tepat, yaitu karakter yang memiliki nilai heritabilitas tinggi.

Penapisan plasma nutfah padi untuk toleransi terhadap cekaman suhu tinggi telah dilakukan dan diperoleh beberapa genotipe yang dianggap toleran dan peka terhadap cekaman suhu tinggi (Mubarrozah, 2013; Wirnas et al., 2015). Genotipe terpilih dijadikan sebagai tetua persilangan untuk menghasilkan populasi bersegregasi. Tujuan penelitian ini adalah untuk memperoleh informasi tentang pola pewarisan karakter agronomi padi pada populasi F2 untuk karakter toleransi cekaman suhu tinggi dan menyeleksi individuindividu F2 terbaik.

\section{BAHAN DAN METODE}

Penelitian dilakukan di rumah kaca Kebun Percobaan University Farm IPB, Cikabayan, Dramaga, Bogor. Penelitian dilaksanakan bulan September 2014 sampai Januari 2015. Pengamatan pascapanen dilakukan di Laboratorium Pemuliaan Tanaman, Departemen Agronomi dan Hortikultura, Fakultas Pertanian, Institut Pertanian Bogor. Bahan tanam yang digunakan adalah tetua P1 (IPB 4S) sebanyak 20 individu, P2 (Situ Patenggang) sebanyak 20 individu, dan F2 hasil persilangan IPB 4S x Situ Patenggang sebanyak 210 individu.

Media tanam yaitu ember yang diisi dengan campuran tanah dan pupuk kandang perbandingan 2:1. Benih disemai pada bak plastik di tempat persemaian dengan media tanam tanah dan pupuk kandang dengan perbandingan 1:1. Bibit hasil persemaian dipindah tanam setelah berumur 14 hari ke media tanam dalam ember. Bibit ditanam satu bibit per ember. Pupuk urea diberikan sebanyak dua kali yaitu
$1 / 2$ bagian diberikan satu minggu setelah tanam (MST) dan sisanya pada 3 MST. Perlakuan cekaman suhu tinggi diberikan dengan membiarkan tanaman berada di rumah kaca dengan suhu rata-rata sebesar $38^{\circ} \mathrm{C}$. Tanaman ditumbuhkan dalam kondisi menyerupai sawah dengan sistem pengairan berselang (intermittance system). Sejak awal tanam hingga 54 HST kondisi tanaman sangat terganggu akibat tercekam suhu tinggi. Oleh karena itu menjelang fase vegetatif akhir (55 HST) tanaman dikeluarkan dari rumah kaca dengan tujuan untuk mengoptimalkan pertumbuhan tanaman dan saat fase generatif awal (71 HST) tanaman dimasukkan kembali ke rumah kaca.

Pengamatan dilakukan untuk karakter tinggi tanaman saat panen, jumlah anakan total dan produktif, kehijauan daun saat 105 HST yang diukur dengan menggunakan SPAD 502 (Minolta) pada daun yang telah membuka sempurna, lama pengisian biji, panjang malai, jumlah gabah total, jumlah gabah bernas, dan jumlah gabah hampa per malai, bobot gabah bernas per tanaman, dan bobot 100 butir.

Uji kenormalan menggunakan program Minitab 14 digunakan untuk menduga jumlah dan aksi gen yang mengendalikan suatu karakter berdasarkan nilai skewness dan kurtosis (Roy, 2000). Analisis data dilanjutkan untuk menghitung ragam fenotipe dan lingkungan dan serta pendugaan ragam genotipe, heritabilitas arti luas, dan nilai koefisien keragaman genetik. Formula yang digunakan untuk menghitung nilai parameter genetik dan koefisien keragaman genetik (KKG) mengikuti formula yang dikemukakan oleh Roy (2000). Seleksi segregan berdaya hasil tinggi menggunakan intensitas seleksi 25\% dan diferensial seleksi dihitung menurut Falconer dan Mackay (1996).

\section{HASIL DAN PEMBAHASAN}

\section{Keragaan Tetua dan Populasi F2 Padi}

Suhu rata-rata selama penelitian mencapai $24.7{ }^{\circ} \mathrm{C}$ (suhu minimum) dan $42.3{ }^{\circ} \mathrm{C}$ (suhu maksimum) pada fase vegetatif(0-54 HST), sedangkan saat fase vegetatif akhir (55$70 \mathrm{HST}$ ), suhu rata-rata mencapai $24.6{ }^{\circ} \mathrm{C}$ (suhu minimum) dan $34.4^{\circ} \mathrm{C}$ (suhu maksimum). Saat fase generatif (71 HSTpanen), suhu harian minimum mencapai $27.49^{\circ} \mathrm{C}$ dan suhu maksimum $38.59^{\circ} \mathrm{C}$. Awal panen (110 HST) suhu harian maksimum mencapai $39.67^{\circ} \mathrm{C}$ (Gambar 1). Kondisi suhu selama penelitian menunjukkan tanaman tercekam suhu tinggi.

Menurut Yoshida (1978), suhu optimal untuk stadia pembentukan anakan berada pada kisaran suhu $25-31{ }^{\circ} \mathrm{C}$, stadia antesis suhu optimum berada pada kisaran $30-33^{\circ} \mathrm{C}$ dan stadia pematangan pada suhu $20-29^{\circ} \mathrm{C}$ (Gambar 1 ). Jagadish et al. (2007) menyatakan bahwa paparan suhu $33.7^{\circ} \mathrm{C}$ sekitar 1 jam dapat menginduksi sterilitas.

Penampilan pertumbuhan dan perkembangan tanaman terlihat terganggu selama berada di rumah kaca dari awal tanam hingga menjelang fase vegetatif akhir tanaman, yang ditandai dengan: tinggi tanaman yang tidak bertambah, penggulungan daun (leaf rolling) dan jumlah anakan yang 


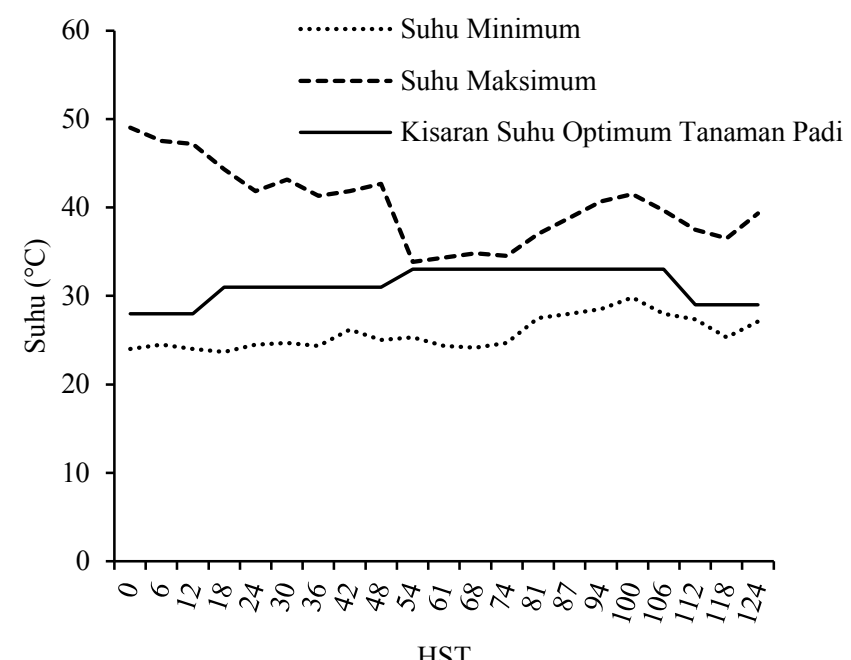

Gambar 1. Suhu maksimum dan minimum selama pertumbuhan tanaman

cenderung sedikit dan tidak bertambah. Oleh karena itu untuk memberikan kesempatan pertumbuhan dan perkembangan yang optimal maka menjelang fase vegetatif akhir tanaman (55 HST) dikeluarkan dari rumah kaca. Adapun suhu ratarata mencapai $24.64{ }^{\circ} \mathrm{C}$ (suhu minimum) dan $34.42{ }^{\circ} \mathrm{C}$ (suhu maksimum) selama tanaman berada di luar rumah kaca. Memasuki fase generatif (71 HST) semua tanaman dimasukkan kembali ke dalam rumah kaca. Hal yang sama juga pernah dilakukan oleh Ginting (2014).

Berdasarkan hasil analisis data diketahui bahwa nilai tengah semua karakter yang diamati berbeda nyata di antara kedua tetua, kecuali pada karakter bobot 100 butir dan jumlah gabah hampa per malai (Tabel 1). Nilai tengah karakter agronomi tetua IPB 4S pada penelitian ini terlihat lebih unggul pada hampir semua karakter dibandingkan tetua Situ Patenggang. Hal ini di duga karena varietas IPB
4S merupakan varietas unggul baru yang berdaya hasil hasil tinggi namun sangat peka terhadap cekaman suhu tinggi berdasarkan hasil penapisan yang dilakukan oleh Mubarrozah (2013) dan Wirnas et al. (2015), sementara varietas Situ Patenggang merupakan varietas yang toleran terhadap cekaman suhu tinggi namun berdaya hasil rendah.

Nilai tengah populasi F2 untuk karakter agronomi yang meliputi jumlah gabah bernas per malai dan bobot gabah bernas per tanaman melebihi nilai tengah dari kedua tetua (Tabel 1). Hal ini berarti terdapat segregansegregan potensial yang memiliki keragaan yang lebih baik dibandingkan kedua tetuanya. Segregan transgresif terjadi karena adanya rekombinasi dari kedua tetua (Jambormias et al., 2015).

\section{Aksi Gen yang Mengendalikan Karakter Agronomi Padi pada Kondisi Suhu Tinggi}

Karakter-karakter kuantitatif dikendalikan oleh banyak gen (Roy, 2000). Jumlah dan aksi gen yang mengendalikan suatu karakter dapat diduga berdasarkan analisis pola sebaran yang ditunjukkan oleh nilai skewness dan kurtosis. Pola sebaran karakter jumlah gabah bernas, jumlah gabah hampa, jumlah gabah total, tinggi tanaman saat panen, bobot gabah bernas dan bobot 100 butir terdapat pada Gambar 2 . Nilai skewness dan kurtosis untuk karakter agronomi yang diamati ditampilkan pada Tabel 2.

Hasil uji Z terhadap nilai skewness dan kurtosis untuk karakter jumlah anakan produktif, jumlah anakan total, dan bobot gabah bernas berbeda tidak nyata. Hal ini berarti bahwa karakter jumlah anakan produktif, jumlah anakan total, jumlah gabah total dan bobot gabah bernas memiliki sebaran normal dan kontinu dikendalikan banyak gen dengan aksi gen aditif (Gambar 2). Terjadinya fiksasi gen-gen aditif pada generasi awal sangat diinginkan pemulia karena akan diwariskan pada generasi lanjut (Sihaloho et al., 2015).

Tabel 1. Nilai tengah karakter agronomi tetua padi IPB 4S, Situ Patenggang, dan F2 hasil persilangan IPB 4S dan Situ Patenggang pada kondisi tercekam suhu tinggi

\begin{tabular}{lccccc}
\hline Karakter & IPB 4S & Situ Patenggang & P-value & F2 & Kisaran F2 \\
\hline Jumlah anakan produktif & 12.8 & 20.5 & $0.00^{* *}$ & 17.1 & $1.0-36.0$ \\
Jumlah anakan total & 15.3 & 27.7 & $0.00^{* *}$ & 21.7 & $7.0-40.0$ \\
Kehijauan daun 105 HST & 45.5 & 41.6 & $0.00^{* *}$ & 44.4 & $35.8-54.5$ \\
Lama pengisian biji (hari) & 32.7 & 28.3 & $0.01^{* *}$ & 31.5 & $22.0-40.0$ \\
Tinggi tanaman panen (cm) & 140.9 & 107.9 & $0.00^{* *}$ & 140.3 & $91.0-177.0$ \\
Panjang malai (cm) & 29.3 & 26.3 & $0.00^{* *}$ & 27.9 & $15.2-35.2$ \\
Jumlah gabah bernas per malai & 164.8 & 64.1 & $0.00^{* *}$ & 143.5 & $0.0-305.0$ \\
Jumlah gabah hampa per malai & 66.4 & 67.9 & 0.81 & 104.9 & $14.0-309.0$ \\
Jumlah gabah total per malai & 231.3 & 132.0 & $0.00^{* *}$ & 249.1 & $29.0-499.0$ \\
Bobot gabah bernas per tanaman $(\mathrm{g})$ & 35.7 & 26.1 & $0.02^{*}$ & 36.5 & $0.0-80.6$ \\
Bobot 100 butir $(\mathrm{g})$ & 2.3 & 2.1 & 0.08 & 2.0 & $0.0-3.1$ \\
\hline
\end{tabular}

Keterangan: $*=$ nyata pada $\alpha 0.05 ; * *=$ sangat nyata pada $\alpha 0.01 ;$ tn $=$ tidak nyata berdasarkan uji-t antara tetua IPB $4 \mathrm{~S}$ dan Situ Patenggang 

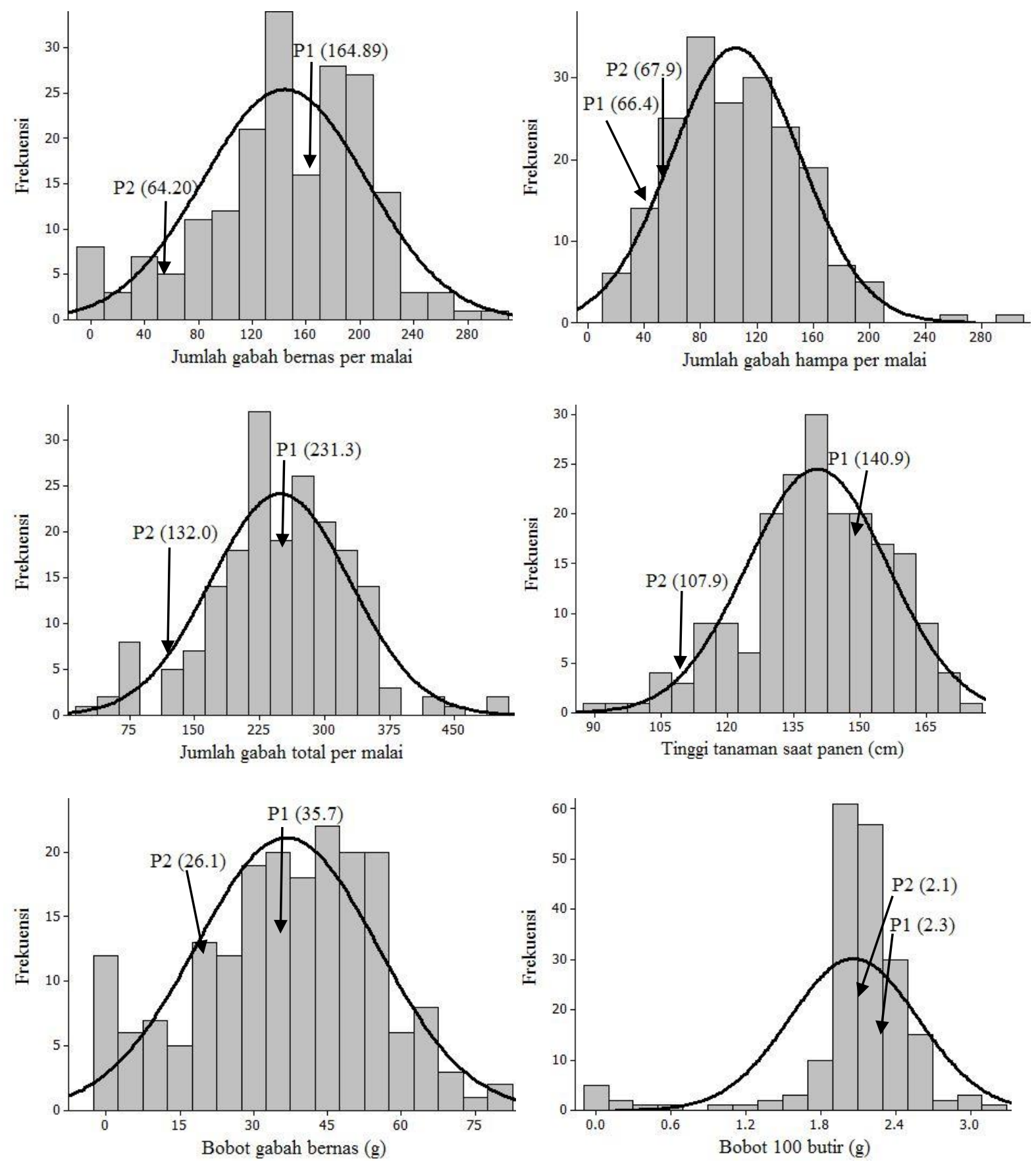

Gambar 2. Pola sebaran karakter agronomi populasi F2 hasil persilangan antara padi IPB 4S dan Situ Patenggang

Aksi gen yang menyebabkan keragaman pada tinggi tanaman, panjang malai, jumlah gabah bernas, bobot 100 butir, dan jumlah gabah hampa adalah aditif dan epistasis (Tabel 2). Karakter tinggi tanaman, panjang malai, jumlah gabah bernas, bobot 100 butir, dan jumlah gabah hampa memiliki sebaran tidak normal. Menurut Roy (2000), grafik tidak menyebar normal terjadi karena keterlibatan gen-gen non aditif, pengaruh lingkungan yang besar, pautan gen, dan adanya gen mayor dalam mengendalikan keragaman pada populasi F2. Hal ini sesuai dengan pendapat Jayaramachandran (2010) yang mengatakan bahwa karakter kuantitatif pada tanaman yang pola sebarannya menjulur ke kiri atau ke kanan menunjukkan adanya pengaruh lingkungan, interaksi genotipe dan lingkungan, pautan gen, atau epistasis.

\section{Pendugaan Nilai Ragam Genetik dan Heritabilitas}

Pendugaan nilai komponen ragam dan heritabilitas dilakukan untuk mengetahui proporsi keragaman yang disebabkan oleh faktor genetik dan lingkungan (Roy, 2000). Hasil analisis menunjukkan bahwa karakter jumlah anakan produktif, jumlah anakan total, tinggi tanaman saat panen, panjang malai, jumlah gabah bernas, jumlah gabah hampa, jumlah gabah total, bobot gabah bernas, bobot 100 butir, memiliki nilai heritabilitas arti luas yang tinggi (Tabel 3). 
Tabel 2. Pendugaan aksi gen dan jumlah gen karakter agronomi populasi F2 hasil persilangan padi IPB 4S dan Situ Patenggang pada kondisi tercekam suhu tinggi

\begin{tabular}{lccccccccc}
\hline Karakter & S & SES & Uji Z S & $\begin{array}{c}\text { Aksi } \\
\text { gen }\end{array}$ & K & SEK & $\begin{array}{c}\text { Uji Z K } \\
\text { Jumlah } \\
\text { gen }\end{array}$ \\
\hline Jumlah anakan produktif & -0.02 & 0.17 & $-0.10 \mathrm{tn}$ & Ad & 0.43 & 0.35 & $1.25 \mathrm{tn}$ & Banyak \\
Jumlah anakan total & 0.11 & 0.17 & $0.63 \mathrm{tn}$ & Ad & 0.36 & 0.35 & $1.03 \mathrm{tn}$ & Banyak \\
Kehijauan daun 105 HST & -0.06 & 0.17 & $-0.32 \mathrm{tn}$ & EA & 1.42 & 0.35 & $4.10^{* *}$ & Sedikit \\
Lama pengisian biji & -0.15 & 0.17 & $-0.83 \mathrm{tn}$ & EA & -1.00 & 0.35 & $-2.87 * *$ & Banyak \\
Tinggi tanaman panen & -0.45 & 0.17 & $-2.57 * *$ & EA & 0.14 & 0.35 & 0.39 tn & Banyak \\
Panjang malai & -0.61 & 0.17 & $-3.49 * *$ & EA & 1.70 & 0.35 & $4.91^{* *}$ & Sedikit \\
Jumlah gabah bernas per malai & -0.47 & 0.17 & $-2.73 * *$ & EA & 0.05 & 0.35 & 0.15 tn & Banyak \\
Jumlah gabah hampa per malai & 0.68 & 0.17 & $3.90^{* *}$ & EA & 1.40 & 0.35 & $4.03 * *$ & Sedikit \\
Jumlah gabah total per malai & -0.17 & 0.17 & $-0.96 \mathrm{tn}$ & Ad & 0.74 & 0.35 & $2.13^{*}$ & Sedikit \\
Bobot gabah bernas per tanaman & -0.26 & 0.17 & $-1.49 \mathrm{tn}$ & Ad & -0.47 & 0.35 & -1.35 tn & Banyak \\
Bobot 100 butir & -2.39 & 0.17 & $-13.67 * *$ & EA & 8.60 & 0.35 & $24.71^{* *}$ & Sedikit \\
\hline
\end{tabular}

Keterangan: $\mathrm{S}=$ skewness; SES = standar error skewness; $\mathrm{K}=$ kurtosis; $\mathrm{SEK}=$ standar error kurtosis; $\mathrm{EA}=$ epistasis aditif; Ad = aditif; $*$ = nyata pada $\alpha 0.05 ; * *=$ sangat nyata pada $\alpha 0.01 ; \mathrm{tn}=$ tidak nyata

Hal ini menunjukkan bahwa karakter-karakter tersebut lebih banyak dikendalikan oleh faktor genetik dibandingkan faktor lingkungan. Karakter yang memiliki nilai heritabilitas yang tinggi dapat dipertimbangkan untuk menjadi karakter seleksi (Rostini et al., 2006; Wirnas et al., 2006; Susilaningsih et al., 2008; Suharsono dan Jusuf, 2009). Pendugaan heritabilitas merupakan parameter genetik untuk memilih sistem seleksi yang efektif dan memperoleh kemajuan genetik dari sebuah seleksi (Erkul et al., 2010; Syukur et al., 2011). Karakter jumlah anakan produktif, jumlah gabah bernas, dan bobot gabah bernas merupakan karakter yang memiliki nilai KKG tergolong tinggi (Tabel 3). Nilai KKG yang tinggi menunjukkan suatu peluang terhadap usaha-usaha perbaikan yang efektif melalui seleksi sehingga seleksi terhadap karakter kuantitatif dapat dilakukan tanpa mengabaikan nilai tengah populasi yang bersangkutan (Febrianto et al., 2015)

Karakter yang memiliki heritabilitas yang tinggi, keragaman genetik yang tinggi dan dikendalikan aksi gen aditif dapat dijadikan sebagai kriteria seleksi pada generasi awal. Berdasarkan hasil penelitian ini maka karakter yang dapat dijadikan karakter seleksi pada generasi awal untuk perbaikan daya adaptasi padi terhadap cekaman suhu tinggi adalah jumlah anakan produktif, jumlah anakan total, jumlah gabah total, dan bobot gabah bernas. Terpilihnya karakter bobot gabah bernas sebagai kriteria seleksi sangat menguntungkan untuk mendapatkan genotipe F2 yang toleran cekaman suhu tinggi. Hal ini sesuai dengan pendapat Mohammadi et al. (2007) yang menyatakan bahwa karakter bobot biji di bawah kondisi cekaman suhu tinggi merupakan

Tabel 3. Nilai pendugaan komponen ragam, heritabilitas dan koefisien keragaman genetik (KKG) arti luas populasi F2 (hasil persilangan padi IPB 4S dan Situ Patenggang) pada kondisi tercekam suhu tinggi

\begin{tabular}{lrrrr}
\hline Karakter & \multicolumn{1}{c}{$\sigma^{2} \mathrm{p}$} & \multicolumn{1}{c}{$\sigma^{2} \mathrm{~g}$} & $\mathrm{~h}^{2} \mathrm{bs}$ & $\mathrm{KKG}$ \\
\hline Jumlah anakan produktif & 42.66 & 27.10 & 63.52 & 30.40 \\
Jumlah anakan total & 40.82 & 22.64 & 55.46 & 21.85 \\
Kehijauan daun 105 HST & 7.40 & 1.87 & 25.25 & 3.08 \\
Lama pengisian biji & 23.09 & 7.30 & 31.62 & 8.57 \\
Tinggi tanaman saat panen & 251.51 & 228.25 & 90.75 & 10.77 \\
Panjang malai & 8.69 & 6.48 & 74.62 & 9.10 \\
Jumlah gabah bernas per malai & $3,797.43$ & $2,680.79$ & 70.60 & 36.08 \\
Jumlah gabah hampa per malai & $2,110.70$ & $1,094.63$ & 51.85 & 31.53 \\
Jumlah gabah total per malai & $6,443.30$ & $4,899.42$ & 76.04 & 28.09 \\
Bobot gabah bernas per tanaman & 340.67 & 172.83 & 50.73 & 35.95 \\
Bobot 100 butir & 0.22 & 0.14 & 62.38 & 17.82 \\
\hline
\end{tabular}

Keterangan: $\sigma^{2} \mathrm{p}=$ ragam fenotipik; $\sigma^{2} \mathrm{~g}=$ ragam genetik; $\mathrm{h}^{2} \mathrm{bs}=$ heritabilitas arti luas; $\mathrm{KKG}=$ koefisien keragaman genetik 
karakter yang lebih baik untuk menyaring genotipe toleran. Hal yang sama juga dilakukan oleh Tenorio et al. (2013) untuk penapisan plasma nutfah yang toleran terhadap cekaman suhu tinggi pada tanaman padi.

Berdasarkan nilai heritabilitas yang tinggi maka dapat diusulkan metode seleksi untuk generasi selanjutnya adalah metode seleksi pedigree seperti dilaporkan oleh Wardani et al. (2015) yang melakukan seleksi pedigree pada generasi awal dengan menggunakan karakter terpilih berdasarkan nilai heritabilitas tinggi pada tanaman gandum.

\section{Diferensial Seleksi}

Seleksi tunggal merupakan seleksi yang dilakukan hanya pada satu karakter saja, yaitu karakter bobot biji per tanaman dengan tujuan memperoleh individu F2 yang berdaya hasil tinggi. Kelemahan seleksi berdasarkan karakter tunggal yaitu terfokus pada satu karakter seleksi saja tanpa memperhatikan pengaruh dari berbagai karakter yang diamati. Kelemahan ini dapat ditutupi melalui seleksi berdasarkan beberapa karakter sekaligus.
Berdasarkan nilai heritabilitas yang tinggi, keragaman genetik yang tinggi dan aksi gen aditif maka penggunaan beberapa karakter untuk diferensial seleksi adalah bobot gabah bernas, jumlah anakan produktif, jumlah anakan total dan jumlah gabah total (Tabel 4). Berdasarkan bobot gabah bernas per tanaman dan seleksi multikarakter (jumlah anakan produktif, jumlah anakan total, jumlah gabah total, dan bobot gabah bernas) terseleksi 50 segregan F2 terbaik berdaya hasil tinggi pada kondisi cekaman suhu tinggi. Seleksi dengan menggunakan 4 karakter seleksi akan memberikan perbaikan nilai tengah bobot gabah bernas, menurunkan jumlah gabah hampa (dimana jumlah gabah hampa yang sedikit akan berarti bagi pemulia tanaman), dan memberikan perbaikan terhadap bobot 100 butir. Seleksi beberapa karakter pada penelitian ini mempunyai keunggulan yaitu meningkatnya nilai tengah jumlah anakan produktif, jumlah anakan total, panjang malai, jumlah gabah bernas, dan jumlah gabah total, sedangkan kelemahannya adalah meningkatnya tinggi tanaman, lama pengisian biji, dan menurunnya kehijauan daun 105 HST yang tidak diinginkan pemulia.

Tabel 4. Diferensial seleksi langsung dan tidak langsung populasi F2

\begin{tabular}{lccc}
\hline Karakter & $\bar{x}_{\mathrm{D}}$ & $\bar{x}_{\text {BВ }}$ & $\bar{x}_{\mathrm{M}}$ \\
\hline Bobot gabah bernas per tanaman (g) & 36.56 & 58.43 & 51.25 \\
Jumlah anakan produktif & 17.12 & 24.96 & 18.40 \\
Jumlah anakan total & 21.77 & 29.30 & 25.84 \\
Kehijauan daun 105 HST & 44.40 & 47.60 & 22.80 \\
Lama pengisian biji (hari) & 31.54 & 37.58 & 78.92 \\
Tinggi tanaman panen (cm) & 140.35 & 159.36 & 41.95 \\
Panjang malai (cm) & 27.99 & 31.39 & 32.60 \\
Jumlah gabah bernas per malai & 144.24 & 213.70 & 141.84 \\
Jumlah gabah hampa per malai & 104.91 & 163.36 & 28.86 \\
Jumlah gabah total per malai & 240.16 & 377.06 & 179.92 \\
Bobot 100 butir (g) & 2.07 & 2.51 & 2.31 \\
\hline
\end{tabular}

Keterangan: $\bar{x}_{\mathrm{D}}=$ rata-rata populasi dasar; $\bar{x}_{\mathrm{Bвт}}=$ rata-rata genotipe terseleksi berdasarkan bobot biji per tanaman; $\bar{x}_{\mathrm{M}}=$ rata-rata genotipe terseleksi berdasarkan bobot gabah bernas, jumlah anakan produktif, jumlah gabah total dan jumlah anakan total

\section{KESIMPULAN}

Populasi F2 padi hasil persilangan IPB 4S dan Situ Patenggang pada kondisi tercekam suhu tinggi memiliki nilai tengah di antara nilai tengah kedua tetuanya, namun terdapat individu-individu yang keragaan lebih baik dari kedua tetuanya. Karakter bobot gabah bernas, jumlah anakan produktif, dan jumlah gabah total dikendalikan oleh aksi gen aditif, memiliki nilai heritabilitas yang tinggi, dan koefisien keragaman genetik yang luas sehingga dapat digunakan sebagai karakter seleksi pada generasi awal. Terpilih sebanyak lima puluh segregan terbaik berdasarkan karakter bobot gabah bernas, jumlah anakan produktif, jumlah anakan total dan jumlah gabah total.

\section{UCAPAN TERIMA KASIH}

Terima kasih disampaikan kepada DIKTI yang telah membiayai penelitian ini melalui hibah Desentralisasi IPB Tahun 2014 dengan Kontrak nomor: 083/SP2H/PL/Dit. Litabmas/II/2015 atas nama Desta Wirnas.

\section{DAFTAR PUSTAKA}

Erkul, A., A. Ünay, C. Konak. 2010. Inheritance of yield and yield components in a bread wheat (Triticum aestivum L.) cross. Turk. J. Field Crops 15:137-140. 
Falconer, D.S., T.F.C Mackay. 1996. Introduction to Quantitative Genetics. 4th ed. Adison-Wesley Longman, Harlow, UK.

Febrianto, E.B., Y. Wahyu, D. Wirnas. 2015. Keragaan dan keragaman genetik karakter agronomi galur mutan putatif gandum generasi M5. J. Agron. Indonesia 43:52-58.

Ginting, L.E.E. 2014. Respon pertumbuhan beberapa genotipe F1 padi (Oryza sativa L.) terhadap cekaman suhu tinggi. Skripsi. Institut Pertanian Bogor. Bogor.

[IPCC] Intergovernmental Panel on Climate Change. 2007. Climate Change 2007: The Physical Science Basis. Contribution of Working Group I to the Fourth Assessment Report of the Inter-governmental Panel on Climate Change. p. 29-34. In S. Solomon, D. Qin, M. Manning, Z. Chen, M. Marquis, K.B. Averyt, M. Tignor, H.L. Miller (Eds.). Cambridge University Press, Cambridge, UK.

Jagadish, S.V.K., P.Q. Craufurd, T.R. Wheeler. 2007. High temperature stress and spikelet fertility in rice (Oryza sativa L.). J. Exp. Bot. 58:1627-1635.

Jagadish, S.V.K., P.Q. Craufurd, T.R. Wheeler. 2008. Phenotyping parents of populations of rice for heat tolerance during anthesis. Crop Sci. 48:1140-1146.

Jagadish, S.V.K., R. Muthurajan, Z.W. Rang, R. Malo, S. Heuer, J. Bennett, P.Q. Craufurd. 2011. Spikelet proteomic response to combined water deficit and heat stress in rice (Oryza sativa cv. N22). Rice 4:111.

Jambormias, E., S. H. Sutjahjo, A.A. Mattjik, Y. Wahyu, D. Wirnas, A. Siregar, J.R. Patty, J.K. Laisina, E.L. Madubun, R.E. Ririhena. 2015. Transgressive segregation analysis of multiple traits in mungbean (Vigna radiata L. Wilczek). SABRAO J. Breed. Genet. 47:201-213.

Jayaramachandran, M., N. Kumaravadivel, S. Eapen, G. Kandasamy. 2010. Gene action for yield attributing characters in segregating generation (M2) of sorghum (Sorghum bicolor L.). Elec. J. Plant Breeding 1:802808.

Krishnalatha, S., S. Sharma. 2012. Identification of maintainers and restorers for WA and Kalinga sources of CMS lines in rice (Oryza sativa L.). Elec. J. Plant Breeding 3:949-951.

Mohammadi, V., M.R. Bihamta, A.A. Zali. 2007. Evaluation of screening techniques for heat tolerance in wheat. Pakistan J. Biol. Sci. 10:887-892.
Mubarrozah, R.H. 2013. Keragaan pertumbuhan dan produksi beberapa varietas padi pada dua kondisi suhu yang berbeda. Skripsi. Institut Pertanian Bogor. Bogor.

Poli, Y., R.K. Basava, M. Panigrahy, V.P. Vinukonda, N.R. Dokula, S.R. Voleti, S. Desiraju, S. Neelamraju. 2013. Characterization of a Nagina22 rice mutant for heat tolerance and mapping of yield traits. Rice 6:36-44.

Prasad, P.V.V., K.J. Boote, L.H. Allen Jr., J.E. Sheehy, J.M.G. Thomas. 2006. Species, ecotype and cultivar differences in spikelet fertility and harvest index of rice in response to high temperature stress. Field Crops Res. 95:398-411.

Rostini, N., E. Yuliani, N. Hermiati. 2006. Heritabilitas, kemampuan genetik dan korelasi karakter daun dengan buah muda, heritabilitas, pada 21 genotipe nenas. Zuriat 17:114-121.

Roy, D. 2000. Plant Breeding Analysis and Exploitation of Variation. Narosa Publishing House, New Delhi, IN.

Susilaningsih, F., D. Ruswandi, N. Hermiati. 2008. Penampilan fenotipik dan beberapa parameter genetik 16 kultivar padi gogo pada sistem tumpangsari 3:1 dengan kacang tanah di Jatinangor. Zuriat 19:154163.

Sihaloho, A.N., Trikoesoemaningtyas, D. Sopandie, D. Wirnas. 2015. Identifikasi aksi gen epistasis pada toleransi kedelai terhadap cekaman aluminium. J. Agron. Indonesia 43:30-35.

Suharsono, M. Jusuf. 2009. Analisis generasi F2 dan seleksi pertama dari persilangan kedelai antara kultivar Slamet dan Wase. J. Agron. Indonesia 37:21-27.

Syukur, M., S. Sujiprihati, R. Yunianti, D.A. Kusumah. 2011. Pendugaan ragam genetik dan heritabilitas karakter komponen hasil beberapa genotipe cabai. J. Agrivigor 10:148-156.

Tang, R.S., J.C. Zheng, Z.Q. Jdi, D.D. Zhang, Y.H. Huang, L.G. Chen. 2008. Possible correlation between high temperature induced floret sterility and endogenous levels of IAA and ABA gas in rice (Oryza sativa L.). Plant Growth Regul. 54:37-43.

Tenorio, F.A., C. Ye, E. Redoña, S. Sierra, M. Laza, M.A. Argayoso. 2013. Screening rice genetic resources for heat tolerance. SABRAO J. Breed. Genet. 45:371381.

Wahid, A., S. Gelani, M. Ashraf, M.R. Foolad. 2007. Heat tolerance in plants: an overview. Environ. Exp. Bot. 61:199-223. 
Wardani, S., D. Wirnas, Y. Wahyu. 2015. Seleksi segregan gandum (Triticum aestivum L.) pada dataran tinggi. J. Agron. Indonesia 43:45-51.

Wassmann R, S.V.K. Jagadish, K. Sumfleth, H. Pathak, G. Howell, A. Ismail, R. Serraj, E. Redoña, R.K. Singh, S. Heuer. 2009. Regional vulnerability of climate change impacts on Asian rice production and scope for adaptation. Adv. Agron. 102:93-105.

Wirnas, D., I. Widodo, Sobir, Trikoesoemaningtyas, D. Sopandie. 2006. Pemilihan karakter agronomi untuk menyusun indeks seleksi pada 11 populasi kedelai generasi F6. Bul. Agron. 34:19-24.

Wirnas, D., R.H. Mubarrozah, M. Noviarini, S. Marwiyah, Trikoesoemaningtyas, H. Aswidinnoor, S.H.
Sutjahjo. 2015. Contibution of genetic $\mathrm{x}$ temperature interaction to performance and variance of rice yield in Indonesia. Int. J. Agr. Agric. Res. 6:112-119.

Yoshida, S. 1978. Tropical Climate and Its Influence on Rice. IRRI Research Paper Series 20. IRRI, Los Baños, PH.

Zhang, T., L. Yang, K. Jiang, M. Huang, Q. Sun, W. Chen, J. Zheng. 2008. QTL mapping for heat tolerance of the tassel period of rice. Mol. Plant Breed. 6:867-873.

Xiao, Y., Y. Pan, L. Luo, G. Zhang, H. Deng, L. Dai, X. Liu, W. Tang, L. Chen, G. Wang. 2011. Quantitative trait loci associated with seed set under high temperature stress at the flowering stage in rice. Euphytica 178:331-338. 